THURSDAY, JULY 6, 1905.

\section{THE EMPIRE AND UNIVERSITY LIFE.}

$W^{\mathrm{B}}$ E publish to-day a statement signed by more than forty professors and heads of departments of the University of Oxford setting forth a scheme for large increase in the facilities for research and for teaching. We have no hesitation in stating that these forty signatures include the majority of Oxford workers with a reputation for learning which extends beyond the borders of that ancient university. They also represent, with singular completeness, the varied lines of research which happily are pursued at Oxford; and it is an encouragement among the many unsatisfactory features in the intellectual life of the nation that they are ready and willing to stand side by side, each sympathising with the needs of other workers, each desiring to grant the fullest opportunities for research on the broadest lines.

They doubtless feel in Oxford, as we recognise in London, and as Britain generally is beginning to know, that the real conflict in this country is not between science and classics, between theology and philosophy, or between the true followers of any branches of learning, but that the great educational struggle of our time and race is of an utterly different kind. On the one side are ranged those who hold that the much needed intellectual inspiration of our youth can only be received in an atmosphere of research, can only be given by men who are themselves researchers; on the opposite side stand those who uphold the ancient Chinese and the modern British educational methods. We recognise to the full the Imperial importance of the subject. Young men instructed by purveyors of second-hand word knowledge are not likely to develop the germs of imagination and originality, and to deal effectively with the problems presented in the modern world which deals with things; and the time in which such development is generally possible is all too brief. When once the critical period of intellectual growth has been devoted solely to the collection and re-collection of material for the examiner, any awakening of original power is rare indeed. We have merely created one Briton the more incapable of using his birthright, out of sympathy with the movement which would help others to gain what he has lost; and his want of sympathy may mean a great deal. He may become a journalist and help to frame the opinion of the nation, he may enter Parliament and help to marshal the educational forces upon which our future existence most surely depends, he may be a power in the Treasury and help to determine the expenditure of the national income, he may become a schoolmaster or a college tutor and do unto others even as he has been done by.

It cannot be disguised that things are in many respects worse than they were half a century ago. The University Commissioners of ${ }^{2} 850$ said of No. I862, voL. 72]
Oxford:- "It is generally acknowledged that both Oxford and the country at large suffer greatly from the absence of a body of learned men devoting their lives to the cultivation of science, and to the direction of academical education."

The commissioners of a quarter of a century later did, indeed, largely increase the number of university professors, but it left them powerless-muzzled lions chained by the leg. The whole power of influencing the passing generations of young men it left in the hands of a score of independent corporations-nearly all of them ancient, and with noble traditions of high learning and profound research; but, in the intellectual backwater of our time, each has strained to become a petty university and the successful rival of all the other petty universities - the successful rival, that is, in the qualities developed by examination, and in nothing higher. To this end each has freely spent its endowment in entrance scholarships to compete with others for the men who will do best in examinations, and each has striven to secure, before and beyond all others, the most successful purveyor of knowledge which will be useful in examinations. We say, intentionally and deliberately, that each college has done these things, but are far from implying that all of them have no higher aims at the present time. We are only too glad to recognise in recent years a change of spirit which has led to significant departures from the scheme of the last university commissioners. Magdalen, New College, and Brasenose have been noble leaders in a noble cause-the return of Oxford to ideals of learning which have been suppressed, but not altogether killed, by a false and injurious educational system. We gladly recognise clear evidence of the same spirit in other societies, and we are well aware that others, again, strongly desire to make provision for the highest learning, but are unable to do so while their whole available funds barely suffice to enable them to keep their place in the unfortunate and wasteful inter-collegiate competition which dominates both our ancient universities. There is, however, one college in which the necessity for such competition is reduced to a minimum, and it is precisely here that the last commissioners inflicted the crowning injury upon the intellectual life of Oxford-they set their seal on the existing constitution of All Souls. A college almost without the responsibility and the care of undergraduates is created, it would seem, to be the home of the highest learning and research. And what is it? Well, apart from a distinguished professoriate, a generous assistance to the Bodleian, and a rare and occasional election of men of learning to her fellowships-for all of which we freely and gladly express our gratitude-All Souls merely exists in order to encourage the worst features of an intellectual training which exists by and for examination alone. Only recently the governing body rejected the movement, which happily existed among some of the members, to ask for evidence of original power in the candidates who compete for the fellowships. Yet 
All Souls might readily do as much for learning in Oxford by her fellowships as she now does to prevent learning - as she now does to turn the attention of the ablest men towards what will pay in examinations, and to shut their ears to the still small voice of latent imagination and original power. If All Souls gave her two fellowships each year for evidence of research, the ablest of the men studying the subjects of her choice would demand of their teachers inspiration and guidance in the highest work. Where the ablest men lead others would soon follow, and the whole intellectual atmosphere would rapidly change.

All Souls unaided could do an immense deal to induce the other colleges to provide higher teaching, or, even better, to encourage their men to get help outside the college walls. As it is, she provides the strongest of all the forces which chain Oxford to that unhappy infatuation which has had so disastrous an effect on the imagination, the initiative, the resourcefulness of the nation.

The title of this article was chosen in the profound conviction that interests much wider and more important than those of Oxford and Cambridge are at stake. Our ancient universities have heavy responsibilities, extending far beyond their historic walls. Every new university and university college in the Empire draws its teachers from Oxford and Cambridge, and, for good or for evil, moulds the broad, features of its intellectual life upon the pattern supplied by these ancient seats of learning.

In the supreme interests of the Empire, as well as of the university itself, we fully sympathise with the aims of those who desire to render Oxford a more efficient instrument of research and the highest and most stimulating teaching, but we have no right to claim their sympathy or support for our own views on university and collegiate life. It may well be that the onlooker sees weaknesses and obvious measures of reform hidden from those on the spot, or appearing to them as a far-off ideal impossible of realisation, at least in this generation. Speaking for those who watch from without, who admire and would preserve and strengthen the truly inspiring elements of the academic life at both our ancient universities, we would gladly see them subject to the following simple, but, as we believe, efficient measure of reform.

The whole of the teaching should be entirely under the control of the university, which in its boards already possesses at least the foundation of the necessary apparatus. The college fellowships should be given in part for university teaching combined with original work and in part for research alone, to be held only during the continuance of investigation. A career would thus be open for originality of a high order, and the ablest men would flock to our ancient seats of learning and render them indeed worthy of the name. Residence in homes of ancient learning would gain added inspiration when the greatest traditions of the past were renewed and maintained. Even with things as they No. 1862 , vol. 72$]$ are, Oxford and Cambridge, though much injured by competitive examinations, have been far less injured than England in general; and this they owe to the residential system. Little thought of, perhaps neglected, by the builders, the head-stone of the educational edifice is here to be found. Where mind meets mind in the free intercourse of youth there springs from the contact some of that fire which, under our present system, is rarely to be obtained in any other way; and not only this, but many other priceless advantages in the battle of life are also conferred. To these influences we owe in large part all that is best in the English character, and so valuable are the qualities thus developed, or at least greatly strengthened, that we regard residential colleges as essential to the success and usefulness of the newer universities. The changes we have advocated in the older universities would only add to this beneficent system increased power for good by substituting for the barren pride of first classes and university prizes the enthusiasm for a society which nobly holds its own in those achievements which bring renown wherever the advancement of learning is held in honour-a sufficient answer to the contention that to deprive a college of teaching is to render it a boarding-house and nothing more. That the advancement of learning is the desire of those who have signed the memorial we do not doubt, however much they may disagree with the methods here suggested for the attainment of their ends. On our part we feel such confidence in the beneficent influence of the increase in efficiency for which they plead, that we should gladly see funds provided for the purpose.

In former centuries the highest learning was encouraged in this country by the munificence of "founders and benefactors"; and we are glad to know that one of the needs set forth in the accompanying statement has already been generously met, and even more than met, by the establishment of a department presided over by a Beit professor of colonial history. But the signs of the times do not encourage us to anticipate any very large or fruitful following of this fine example; and we see no prospect of carrying out the suggested scheme in anything like completeness, except by a re-arrangement of the revenues of the university and the colleges, or by the action of a Government which is convinced that the national well-being is imperilled, the national existence at stake.

THE SARCODINE FAUNA OF DEEP LAKES. Les Sarcodinés des Grands Lacs. By Eugène Penard. Pp. 133. (Geneva: H. Kundig, 1905.)

D. PENARD'S enthusiastic and minute investigations into this group of the Protozoa are well known. In the course of many years' study of the Sarcodina of the Lake of Geneva and of the surrounding country, he became convinced that there is a special sarcodine fauna of deep lakes. The facts on which he founded his theory, already embodied in his 